\title{
J. Skelly Wright and the Limits of Liberalism
}

Louis Michael Seidman

Georgetown University Law Center, seidman@law.georgetown.edu

This paper can be downloaded free of charge from:

https://scholarship.law.georgetown.edu/facpub/1387

http://ssrn.com/abstract=2516395

This open-access article is brought to you by the Georgetown Law Library. Posted with permission of the author. Follow this and additional works at: https://scholarship.law.georgetown.edu/facpub 


\section{J. Skelly Wright and the Limits of Liberalism}

\section{Louis Michael Seidman*}

For over forty years, I have avoided writing academic articles about J. Skelly Wright and Thurgood Marshall - the two extraordinary judges for whom I had the privilege of clerking. I have remained silent, even long after their deaths, because of powerful bonds of affection and loyalty. My fear has been that a tension might arise between these bonds and the norm of objectivity in academic scholarship, to which I try to adhere.

So why this essay? I write in the hope that I can say something about Judge Wright's career that is new and not merely hagiographic, but that neither trades on my personal access to him nor is disloyal to his memory. I also rely on the following warning to readers: Judge Wright was my first employer after law school. I cannot possibly be objective about this decent, kind, and heroic man who, more than anyone outside of family, was responsible for the subsequent direction of my life. Consumers of this essay should read it with this caveat in mind.

J. Skelly Wright was the most courageous and influential lower court judge of his generation. Wright was quiet, modest, even awkward in his personal interactions, but that demeanor masked a fierce determination to use his power to root out injustice. Throughout his career, he fearlessly defended the rights of the poor and dispossessed. He did so in times and places where standing up for these rights was deeply unpopular and, on occasion, placed him in physical danger.

\footnotetext{
* Carmack Waterhouse Professor of Constitutional Law, Georgetown Universit Law Center.

Thanks to Peter Edelman, Anne Fleming, Michael Harper, Allegra McLeod, Girardeau Spann, Geoffrey Stone, Silas Wasserstrom, and Robin West for providing comments on an earlier version of this article. I received superb research help from Richard Kelley.
} 
Judge Wright put to shame the "scholastic mandarins" ${ }^{1}$ who insisted that some sort of immutable principle forced judges to acquiesce in the systematic and persistent denial of basic human rights to millions of ordinary Americans. Of course, he believed in principles, but the principles he believed in were not about "judicial restraint" in the face of injustice. They were not "neutral" as between freedom and oppression. By candidly and self-consciously using the law as a means to achieve social change, he pushed legal liberalism to its limits. ${ }^{2}$

This is an essay about how Skelly Wright confronted those limits - limits that bounded his effectiveness and left his professional career on the knife's edge between triumph and tragedy.

I.

What were the aspirations and limits of legal liberalism? First the aspirations: The core commitment of legal liberals was to the use of judge-made law as an instrument of social justice. Legal liberals differed from both an earlier and a later generation of legal progressives. An earlier generation, exemplified by judges like Learned Hand and Felix Frankfurter, was heavily influenced by the Lochner experience. These progressives thought that the best that could be hoped for was a mutual disarmament treaty under which the left and the right both agreed not to use judicial review to advance their projects. For a later generation, exemplified by legal academics like Larry Kramer and Mark Tushnet, the formative experience was a legal landscape dominated by the Federalist Society and an activist and deeply conservative Supreme Court. These progressives believed that social justice could be achieved only by taming courts to make room for popular mobilization.

1 See J. Skelly Wright, Professor Bickel, the Scholarly Tradition, and the Supreme Court, 84 HARV. L. REV. 769, 777-78 (1971) (referring to "self-appointed scholastic mandarins [who] almost always coat . . criticism with a haughty derision of the Court's powers of analysis and reasoning . . .."

2 For a discussion of the legal liberal tradition, see LAURA KALMAN, THE STRANGE CAREER OF LEGAL LIBERALISM (1996). My description of the tradition differs in some details from Kalman's. 
Legal liberals were different. Their view of the world was formed by the brief moment in history when progressives dominated the Court. Inspired by Brown v. Board of Education and emboldened by significant Warren Court decisions protecting the rights of the dispossessed, they had faith that legal materials and analysis could be marshaled to make American society more just and humane.

This faith, in turn, produced an outpouring of strikingly original legal doctrine. Legal liberals demonstrated that constitutional and common law principles could be reread so as to escape the encrusted, conservative conventional wisdom that had dominated standard discourse. Put differently, they acted on the belief that judges were not limited to the dismal trilemma of choosing among conservatism, restraint, and lawlessness. There was a fourth possibility: Commitment to a version of law that had within it the seeds of progressive transformation. They believed that judges could make this choice if only the judges had the perception to see and the courage to act on these possibilities.

What were the limits of legal liberalism? Here, I want to emphasize two side constraints that disciplined the ambition of legal liberals - side constraints that stemmed from their commitment to legality and their commitment to liberalism.

First, legal liberalism was an intervention within the rule-of-law framework. Unlike some American legal realists who preceded them and some adherents to critical legal studies who followed them, legal liberals were not skeptical about the possibilities of law. On the contrary, their aim was to reclaim law from their conservative opponents - to demonstrate that the law, properly conceived, protected the rights and interests that they favored. It followed from this orientation that rule-of-law values constrained their ambition. Precedent, text, tradition, procedural regularity, and the other standard tools of legal analysis did not have to be interpreted with a stolid lack of imagination, but they did pose outer limits on what could be accomplished. Law was not simply the means by which a liberal program could be implemented; it had claims of its own that demanded respect. 
Second, legal liberals were in fact liberals. They were reformers, not revolutionaries. This stance meant that they took for granted many of the major institutions and cultural assumptions of midtwentieth century America. Of course, they recognized that these institutions and assumptions had given rise to injustice, but they believed that the injustice could be remedied within the existing political and economic framework. This limitation was especially salient with regard to the continued existence of a robust private sphere in general and of a system of market allocations in particular. Privacy was not absolute, and markets were not sacrosanct. Legal liberals were entirely comfortable with substantial government redistribution and market regulation, and they favored significant constraints on oppressive private power. Still, they joined everyone within the bounds of respectable American opinion in embracing a presumptive baseline formed by individual autonomy free from government restraint and market allocations of goods and services.

II.

Skelly Wright occupied a position on the left fringe of legal liberalism. Writing on the occasion of his fellow liberal David Bazelon's twenty-fifth anniversary on the Court of Appeals, Wright joked that "I am probably the only judge on any federal court of appeals who can call Judge David L. Bazelon conservative." ${ }^{3}$ The joke was actually an understatement: In the mid 1970's, it would have been hard to find any judge, sitting on any court in the United States, who was to the left of Judge Wright.

But this description of Wright's position on the political spectrum, while accurate, is also overly simple. It does not fully capture the drama and tension that came with the legal liberalism territory that he occupied. It is therefore important to understand that there were also aspects of Wright's personality and legal views that were quite conservative.

3 J. Skelly Wright, A Colleague's Tribute to Judge David L. Bazelon on the Twenty-fifth Anniversary of His Appointment, 123 U.PA. L. REV. 250, 250 (1974). 
For example, Wright was emphatically conservative in temperament and personal style.

Thomas Grey, one of his favorite law clerks who went on to have a distinguished academic career, perfectly captures this aspect of Wright's personality. Before his clerkship, Grey had been led to believe that Wright was a "revolutionary," an "incongruously robed Man on Horseback, striking with the sword of justice at those whom his messianic intuition identified as oppressors." ${ }^{4}$ When he arrived at Wright's chambers, what he found instead was a man who was "steady, orderly and efficient in his work habits," who was "almost wholly lacking in self-importance" and who exhibited "none of the posturing, none of the publicity seeking, none of the need to insist on his status and wisdom that seem the occupational disease of judges." ${ }^{5}$ Wright's judicial work was "straight forward and unpretentious." ${ }^{6}$ He was a "realist" who believed in "the practical reform of the political process."7

Wright was also a cultural conservative. His life-style was entirely conventional. He was disgusted by even the fairly mild pornography contained in Playboy, ${ }^{8}$ and when told of a former law clerk who used drugs, he was outraged. ${ }^{9}$ He was way ahead of his time in protecting the legal rights of gay men and lesbians ${ }^{10}$, but he was a prisoner of his time when, in one of his published opinions, he referred to homosexuality as "an unfortunate affliction." 11

There was a sense in which Wright was also a legal conservative. His courageous stand against the segregationists who dominated Louisiana politics was rooted in a deep belief in racial justice, but it was also a stand for the rule of law and against people prepared to defy lawful court orders. His views

\footnotetext{
4 Thomas C. Grey, J. Skelly Wright, 7 HASTINGS CON. L. QUART. 857, 873, 873 (1980).

$5 \quad$ Id., at 875.

$6 \quad$ Id., at 876 .

$7 \quad$ Id.

$8 \quad$ Michael S Bernick, The Unusual Odessey of J. Skelly Wright, 7 HASTINGS CON. L. QART. 971,998 (1980). 9 Id.

10 See id., at 995. For cases where Wright voted to defend the rights of homosexuals, see Finley v. Hampton, 473 F. 2d 180, (D.C. Cir. 1972) (Wright, J., dissenting); Adams v. Laird, 420 F. 2d 230 (D.C. Cir. 1969) (Wright, J., dissenting); Dew v. Halaby, 317 F. 2d 582 (D.c. Cir. 1963) (Wright, J., dissenting).

11 Adams v. Laird, 420 F. 2d 230, 24 1 (D.C. Cir. 1969) (Wright, J., dissenting).
} 
about criminal justice were premised on a belief in the efficacy of formal rules and the need to limit the realm of lawless discretion. ${ }^{12}$ Similarly, as Judge Frank Johnson summarized Wright's administrative law decisions, "[h]is basic and most consistent approach is that administrative discretion at all levels of government was created by law, and there is no reason why the law, through judicial review, should be unable to control it."13

More broadly still, even Wright's most radical decrees were always couched in terms of legal commands that, he insisted, dictated particular outcomes. As he wrote in his much-discussed Harvard Law Review article, "Constitutional choices are in fact different from ordinary decisions. The reason is simple: the most important value choices have already been made by the framers of the Constitution." ${ }^{14}$

Wright's early career was fully consistent with this personal and legal conventionalism. ${ }^{15}$ Wright was born into a large family of very modest means, but managed to secure a scholarship that allowed him to attend Loyola University. During his formative years, Louisiana politics was dominated by a true radical - Huey Long -- but, to the extent that Wright was politically aware at all, he appears to have been unsympathetic to Long.

Although never an overt racist, Wright "accepted" segregation. As a United States Attorney, he took an aggressive role in the effort to expel communists from a maritime union. Indeed, one of his most important cases was a successful perjury prosecution of an official of a maritime union who had allegedly lied to a loyalty board about his communist ties.

12 See, e.g., J. Skelly Wright, Beyond Discretionary Justice, 81 YALE L. J. 575, 597 (1972).

13 Frank M. Johnson, Jr., Foreword in ARTHur SELWYN MiLlER, A “CAPACITY FOR OUTRAGE”: THE JUdiCIAL ODESSEY OF J. SKELLY WRIGHT X (1984) [hereinafter cited as “Miller”].

$14 \quad J$. Skelly Wright, Professor Bickel, the Scholarly Tradition, and the Supreme Court, note x, supra, at 784.

15 The biographical information recounted below is drawn from ARTHYUR SELWYN MILLER, A “CAPACITY FOR Outrage": The Judicial OdesSey Of J. SKelly WRIGHT (1984) and Michael S. Bernick, The Unusual Odyssey of J. Skelly Wright, 7 HAST. CON. L. QUART. 971 (1980). 
In his early years as a trial judge in Louisiana, Wright won a national reputation, but not as a liberal reformer. Instead, he was seen as a smart, no-nonsense, and efficient judge who managed to handle a large number of cases by encouraging settlement. While he was sitting on assignment in New York, a columnist for a local newspaper wrote that Wright was "not a weeping Willie for hardened criminals. When he's sitting here, criminals wish they were anywhere else."16

Someone trying to predict Wright's career trajectory based on these early years would have had no trouble guessing that he would go on to become a distinguished and well-regarded jurist. Few would have guessed that he would become the most left-wing judge in America.

But then came the civil rights revolution. Wright's role in that revolution pushed him first into legal liberalism and, ultimately, into a struggle with legal liberalism's limits. The first cases were controversial for their time, but did not immediately ignite the explosion that occurred later. In 1950, he ordered the desegregation of the Louisiana State University (LSU) Law School. Two years later, he ordered desegregation of the University's medical and graduate schools. In 1957, he invalidated a subterfuge designed to exclude African Americans from LSU's undergraduate program. In subsequent years, he ordered elimination of state-mandated segregation in transit systems and sports, and invalidated schemes designed to deprive African Americans of the right to vote.

As Wright's assault on Jim Crow grew more aggressive, opposition became more extreme. He began to receive a barrage of threatening phone calls and letters, and a cross was burned on his lawn. He was forced to leave his house, and marshals accompanied him at all hours of the day and night. Many of his friends cut him off and what social life he had collapsed. As Wright later told a television interviewer:

$16 \quad$ N.Y. Daily Mirror, July 23, 1957, quoted in Michael S. Bernick, note x., supra, at 983. 
You'd walk down the street and you wouldn't know whether or not to smile sweetly at this fellow coming or just hold your peace until he made the first move. This was a constant challenge to you. So you begin to walk along the street, you know, with your eyes down so as not to precipitate this incident, so as to avoid it. And more and more you become a loner. And more and more I became a loner. I had some friends but more and more I became a loner. ${ }^{17}$

Faced with the prospect of social ostracism and the threat of violent retaliation, many other judges backed down. Judge Wright stiffened his spine. Wright had never been part of the Louisiana establishment, but this experience undoubtedly pushed him further toward an outsider's perspective. That perspective, in turn, led to a struggle with legal liberalism's limits - first in the context of "massive resistance" to school desegregation in the deep south, then in a much broader challenge to legal orthodoxy.

III.

One branch of the challenge was to conventional rule-of-law values. In his more expansive moods, Wright could be quite cavalier about these values. He told his biographer, Arthur Selwyn Miller that "[i]f I want to do something, I can find a way to do it," ${ }^{18}$ and he wrote in his Harvard Law Review article that [t]he ultimate test of the Justices' work ... must be goodness." ${ }^{19}$ On the occasion of his appointment to the D.C. Circuit, he characterized the Supreme Court as "more than a law court - it is a policy court, or, if you will, a political court. It is an instrument of government, and while most judges have the habit, through long years of precedent, of looking backward, the Supreme Court must look forward through a knowledge of life, of people, of sociology, of psychology."20

These abstract statements are misleading when read in isolation from Wright's long, legally sophisticated, and footnote laden opinions that provided legal justification for his work. Wright was a

17 "Open Mind," WNBC Television, Transcript, at 21 (1965) as quoted in Michael S. Bernick, note x, supra, at 890. $18 \quad$ Miller at 5.

19 J. Skelly Wright, Professor Bickel, the Scholarly Tradition, and the Supreme Court, note x, supra, at 796. 20 Quoted in Frank T. Read \& Lucy S. McGough, Let Them Be Judged: The Judicial INTEgRation OF The DeEp SOUTH 159 (1978). 
superb lawyer who valued legal craft. Yet, when push came to shove, he did not let craft values interfere with what needed to be done.

The New Orleans school controversy provides a case in point. ${ }^{21}$ As noted above, from one perspective, the battle to integrate the New Orleans school system was a struggle to vindicate the rule of law. Yet, for Judge Wright, at least, the struggle also required an engagement with the limits of law, at least as usually understood.

One cannot fully appreciate the necessity for this engagement without some sense of the kind of opposition that Wright faced in 1960. Wright stood against members of the New Orleans School Board, Louisiana's governor, the state legislature, and the majority of Louisiana's white citizens, all of whom staunchly opposed integration. He had little support from the Eisenhower Justice Department, which was at best ambivalent about Brown, and only limited support from the Supreme Court, which had almost entirely withdrawn from the fray. He and a small band of likeminded and courageous judges in the Fifth Circuit stood virtually alone against officials prepared to use any means available to prevent desegregation.

Faced with this opposition, Wright used methods that were, at best, unorthodox. After he had set a date when school desegregation had to begin, the legislature enacted a statute giving the governor control over the schools. Wright declared the statute unconstitutional. When the legislature responded by passing a bewildering array of other statutes meant to prevent desegregation, including one that made it a criminal offense to assist a racially mixed school, he enjoined the governor, the attorney general, the state police, the national guard, the state superintendent of education, and "all those persons acting in concert with them" from enforcing the laws even though not all these persons were before the court and some were not even named in the decree. The superintendent declared the first

21 The account that follows is drawn from Frank T.; ReAD \& LUCY S. McGough, Let THEM BE JUDGED: THE JUDICIAL INTEgRation OF THE DeEp SOUth 114-163 (1978); JACK BASS, UNLIKEly HeROes 119-133 (1990), and Miller 76-83. 
day of desegregation a school holiday, but Wright enjoined the action and declared the superintendent in contempt. When the state legislature then passed a statute making the date a holiday, Wright entered an extraordinary injunction, so far as I know unprecedented in the history of American law, prohibiting all members of the legislature from passing statutes interfering with desegregation.

Many of these decrees violated standard norms of legality. Given the circumstances, they were certainly defensible - indeed, I would say that they were courageous and deeply right - but they also approach law's limits.

When Wright was appointed to the United States Court of Appeals for the District of Columbia Circuit, he doubtless thought that his days of overseeing the desegregation of public schools were over. He was wrong. Because of a quirk in federal law, all trial judges in the District of Columbia were disqualified from hearing a case brought to challenge putative racial discrimination in District schools. Judge Wright was designated to try the case, and, so, he found himself once again faced with the persistent opposition and personal abuse that came with the attempt to enforce the mandate of Brown v. Board of Education.

One cannot read Judge Wright's resulting initial opinion in Hobson v. Hansen ${ }^{22}$ without feeling astonishment at (and, at least for this reader, nostalgia for) the ambition and commitment of some midtwentieth century legal liberals. It is difficult to imagine any judge in the country producing a document remotely like this today. Much of the opinion consists of page after page of detailed, meticulous, and fair minded findings of fact about the District of Columbia school system. But interspersed among the dry legal findings are expressions of the moral outrage that clearly motivated the enterprise. "In sum," he wrote, "all of the evidence in this case tends to show that the Washington school system is a

$22 \quad 269$ F. Supp. 401 (D.DC 1967). 
monument to the cynicism of the power structure which governs the voteless capital of the greatest country on earth." 23

Some of initial decree that Wright issued was in line with other contemporary desegregation plans. Indeed, one part of the decree was modest by contemporary standards. Instead of ordering "forced bussing," Wright was content to require no more than voluntary transfers of students in overcrowded minority schools to under-utilized white schools.

In other parts of the opinion, however, Wright again pushed liberalism to its limits. Although in some respects segregation in District schools was deliberate or "de jure," he found that in other important respects racially separate schools were not the result of "segregative design." But Wright firmly rejected the view that this lack of intent was legally dispositive:

The complaint that analytically no violation of equal protection vests unless the inequalities stem from a deliberate discriminatory plan is simply false. ...[T]he arbitrary quality of thoughtlessness can be as disastrous and unfair to private rights and the public interest as the perversity of a willful scheme...

[T] he law is too deeply committed to the real, not merely theoretical (and present, not deferred) equality of the Negro's educational experience to compromise its diligence ... when cases raise the rights of the Negro poor. ${ }^{24}$

This approach led Wright to order remedies that were extraordinary even by the standards of the mid1960s.

Most striking was his holding that ability tracking of students violated the Constitution. During the oral argument in Brown v. Board of Education, Thurgood Marshall was asked about problems posed by unequal abilities between black and white children. "Simple," he replied, "Put the dumb Colored 
children with the dumb White children and put the smart Colored children with the smart White children." 25

Judge Wright thought that the problem was anything but simple. The Hobson opinion rejected the standard view that law protects a system of neutral meritocracy. It directly attacked the pretentions of such a system. Tests that purported to measure abstract ability were written for and by white people, and the assumption that white people could unilaterally define standards of merit was racist. It was therefore a mistake to make legal outcomes depend on the futile search for a chimerical "fair" or "unbiased" test of merit. What mattered was not the fairness of the standards, but the ultimate fairness of the outcomes produced by the application of the standards. The stark fact was that the District's tracking system was consigning large numbers of poor and minority students to an education that gave them inferior life chances. For Skelly Wright, that was enough to make the system unconstitutional.

There are other episodes in Wright's career that demonstrate a similar willingness to go to the limits of law. In one famous case, which arose when Wright was an appellate judge on the United States Court of Appeals, ${ }^{26}$ his quiet weekend was interrupted by famed lawyer, Edward Bennett Williams, who was representing Georgetown University Hospital and who sought Wright's help regarding a patient who was refusing to receive a life-saving blood transfusion because of her religious convictions. ${ }^{27}$

Generally, of course, federal appellate judges sit in panels of three and base their decisions on a record compiled by the trial court. They rarely act alone, virtually never hear evidence in their courtroom, and absolutely never go out into the world to seek evidence. On this occasion, however, Judge Wright, acting by himself, drove to the hospital and briefly interviewed the woman, who was

25 Quoted in RiCHARd KLUger, SiMPLE JUSTICE 730 (1975).

26 Application of the President and Directors of Georgetown College, Inc., 331 F. 2d 1000 (1964).

27 The facts recounted here are drawn from id. and Miller at 179-83. 
barely able to speak. Both the woman and her husband indicated that they would not hold themselves responsible for the transfusion if it was ordered by a judge, and Wright signed such an order. After his actions were challenged, he wrote a characteristically careful and lawyer-like opinion defending the legality of what he had done. Yet the last paragraph of the opinion, which no doubt explained his true motivations, suggests his dissatisfaction with the law's limits:

The final, and compelling, reason for granting the emergency writ was that a life hung in the balance. There was no time for research and reflection. Death could have mooted the cause in a matter of minutes, if action were not taken to preserve the status quo. To refuse to act, only to find later that the law required action, was a risk I was unwilling to accept. I determined to act on the side of life. ${ }^{28}$

Judge Wright's willingness to push the law to its limits is evident in more mundane cases as well.

Consider, for example, his extensive engagement with administrative law. As Arthur Miller convincingly demonstrates, Wright's administrative law decisions seem to swing wildly between extreme deference and extreme skepticism toward regulatory agencies. ${ }^{29}$ It would be a mistake, though, to think that his decisions were random or unprincipled. They were almost entirely consistent, but along a dimension different from the dimension that legalists obsess over. When agencies acted to advance progressive values, Wright was prepared to give them considerable leeway. ${ }^{30}$ When they refused to embrace those values, he was prepared to intervene forcefully. ${ }^{31}$ The decisions are deeply principled, but the principles relate to substantive goodness as he understood it rather than to legal neutrality.

These cases demonstrate that Wright's opinions approached the very edge of legalism. What about his commitment to liberalism? Some of Wright's most important decisions also challenged these

28 Application of the President and Directors of Georgetown College, Inc., 331 F. 2d 1000, 1009-10 (1964).

$29 \quad$ See Miller at 89-121.

30 See, e.g., Ethyl Corp. v. Environmental Protection Agency, 541 F. 2d 1,54 (finding that the EPA had a "rational basis" for its actions) (DC Cir. 1975)

31 See, e.g., Calvert Cliffs Coordinating Committee v Atomic Energy Commission 449 F. 2d 1109, 1111 (DC Cir. 1971) ("our duty is to see that important legislative purposes, heralded in the halls of Congress, are not lost or misdirected in the vast hallways of the federal bureaucracy"). 
limits, especially the boundaries defined by liberalism's interlocking commitments to individual autonomy and market allocations.

Georgetown Hospital again provides an example. In his opinion and in later commentary on the case, Wright gave a variety of different reasons for his actions. Several of them challenge core assumptions about individual autonomy.

First, Wright showed a willingness to break down the Millian distinction central to liberalism between self-regarding and other-regarding decision making. On standard liberal premises, the law may intervene when an individual harms others, but not when an individual decision affects only the individual herself. This limitation, in turn, rests on the supposed existence of a sharp line between cases that do and do not produce what economists call "negative externalities."

Wright's opinion constitutes a direct, if largely implicit, assault on this crucial distinction. As the opinion illustrates, all decisions produce negative externalities if one looks hard enough to find them. At common law, the decision to refuse medical treatment was thought to be obviously on the self-regarding side of the line and was therefore an aspect of freedom. But, as Wright pointed out, Ms. Jones' refusal to accept a blood transfusion affected not only her life, but also the life of her small child. Her decision to go untreated was analogous to child abandonment and, therefore, coerced others. ${ }^{32}$

Second, Wright argued that individual preferences, another crucial building block of liberal thought, could not be taken at face value. Preferences were inevitably context dependent, and one therefore could not defer to them without first specifying the appropriate context for their exercise. Perhaps while in the hospital, Ms. Jones "really" opposed transfusion, but, as Wright pointed out, it

32 Application of the President and Directors of Georgetown College, Inc., 331 F2d 1000, 1008 (1964)(“ The patient, 25 years old, was the mother of a seven-month-old child. The state, as parens patriae, will not allow a parent to abandon a child, and so it should not allow this most ultimate of voluntary abandonments. The patient had a responsibility to the community to care for her infant. Thus the people had an interest in preserving the life of this mother.") 
might well be that at a later time, she would be glad that the transfusion had occurred. ${ }^{33}$ The choice was not between respecting and disregarding individual preferences, but between one set of individual preferences and another.

Relatedly, Wright cleverly complicated the distinction between freedom and coercion. As he reconstructed Ms. Jones' state of mind, she did not "want" to have a blood transfusion, but she also did not "want" to die. Moreover, she viewed herself as not morally responsible for a transfusion that occurred against her will. In some sense, then, she "wanted" to have a blood transfusion that she did not want. She was willing to have a blood transfusion so long as it was administered against her will.

Finally, Wright deconstructed yet another important liberal distinction - the difference between feasance and nonfeasance. Liberal theory rests on the assumption that individuals and government alike are responsible for their actions but bear no responsibility for merely "letting things happen." Freedom is equated with passivity, while coercion is associated with intervention. Wright did not see things this way. Of course, ordering a transfusion would have consequences for which he should be held responsible, but doing nothing was also a kind of action that also had consequences. Ultimately, there was no refuge from choice. As Wright put it, "[t]o refuse to act, only to find later that the law required action, was a risk I was unwilling to accept. I determined to act on the side of life." 34

Few of these deconstructive moves are set out explicitly in Wright's opinion. He was, after all, a judge, not a philosopher. Yet they are all there and, when taken together, they constitute a powerful and systematic critique of liberal orthodoxy.

33 See Miller at 186 (quoting Wright in 1982 as observing "How much would you bet that Mrs. Jones and her child are glad today for the decision?")

34 Application of the President and Directors of Georgetown College, Inc., 331 F. 2d 1000, 1009-10 (1964). 
Wright's famous decisions protecting tenants' and consumers' rights $^{35}$ rest on a similar critique of the related liberal preference for market allocations. Conservative critics of Wright's decisions implying a warranty of habitability in residential leases and voiding unconscionable consumer contracts claimed that they made things worse for the very people Wright purported to be protecting. This was true on both on an individual and a systemic level. On the individual level, Wright was ignoring the "revealed preferences" of tenants who signed leases for substandard housing or impoverished consumers who purchased goods on harsh credit terms. Systemically, Wright's decisions were bound to decrease the supply of low-income housing and the availability of credit to poor people, thereby making their lot worse in the long run.

These are serious criticisms, and I discuss them in more detail below. For present purposes, though, the important point is that they rest in part on a liberal view of individual agency that Wright was unwilling to embrace. On standard liberal assumptions, these decisions are entitled to respect because they are manifestations of freedom. But for Wright, the decisions occurred within a context created by government when it regulated or refused to regulate the market. That context pushed tenants and consumers toward particular outcomes. Viewed from this perspective, market "freedom" might actually be disguised coercion, forcing purchasers into transactions that they did not "really" desire. That insight, in turn, related to the attack on the liberal feasance/nonfeasance distinction. Whereas traditional liberals equated freedom with a private sphere and government inaction, for Wright, government passivity opened space for private coercion by unscrupulous landlords and predatory lenders. Government action, in the form of market regulation, might create authentic freedom.

35 See, e.g., Javins v. First National Realty Corp, 428 F. 2d 1071 (DC Cir. 1970); Edwards v. Habib, 397 F. $2 d$ 687 (DC Cir. 1968); Williams v. Walker-Thomas Furniture Co., 350 F.2d 445 (1965). 
This dismantling of the distinctions between freedom and coercion, free markets and regulation, and feasance and nonfeasance has obvious roots in an earlier American legal realist critique of Lochner era decisions. Just as Wright belittled the "freedom" exercised by poor tenants who "chose" to live in rat-infested housing, so too an earlier generation of progressives doubted the "freedom" of workers who "chose" to accept deplorable working conditions. But whereas the earlier critique was in the service of reining in the judicial activism of the Lochner Court, Wright used the techniques to expand judicial power. For American legal realists, the incoherence of the distinctions at the base of liberal theory meant that what the Lochner court treated as constitutional commands were, instead, policy disputes that should be resolved politically. For Wright, the same incoherence supported judicial intervention.

This move, too, pushed against the limits of liberalism. Even as American legal realists dismantled liberal theory, some of them held onto notions of judicial neutrality. Indeed, their central argument was that the Lochner court was acting nonneutrally by obscuring controversial political judgments with constitutional rhetoric. In contrast, Wright was more than ready to align the courts with one side of contested issues of distribution and economic justice - the very thing that most American legal realists condemned.

IV.

As the previous section illustrates, Skelly Wright was not like most legal liberals. He accepted their goals and ambitions, but when it appeared that these goals might be stymied by the supposedly bedrock side constraints of legality or liberalism, he fought back. It did not follow, however, that he could entirely escape from these constraints. In fact, as I argue in this section, the forces of markets, individual choice, and of law itself ultimately defeated many of his projects. 
The failure is most dramatic with regard to school desegregation. Almost as soon as Judge Wright left New Orleans, the school system began to backslide. ${ }^{36}$ Today, the district is almost 90 percent African American, so real integration is a pipedream. The vast majority of students are trapped in a world of urban poverty and isolation. The City seems to have given up not just on integration, but on any sort of public education. It recently closed its last five public schools and now offers only charter school education. ${ }^{37}$ This radical - some would say desperate - experiment may or may not be successful, but even if it succeeds, no one would mistake that success for a vindication of Judge Wright's dream of universal, integrated public education.

The story in the District of Columbia is similar. Even in 1967, when Hobson was decided, the District's school system was so overwhelmingly African American that little real integration was possible.

A personal anecdote reveals the state of play two generations later. I live in a residentially integrated section of the city, but it is virtually unheard of for white people to send their children to the neighborhood junior and senior high schools. An exception proves the rule. A number of years ago, I knew of a large, white family, living a few blocks from us. There was no father in the house, and the mother was barely able to keep track of her children. As the story was told to me, when the time came to send her oldest child to junior high school, not knowing any better, she simply packed him off to the local public school. This school had not seen a white student in years. When the child showed up, the home room teacher immediately recognized that a mistake had been made and shipped the young man off to the principal's office. The principal, in amazement, said "what are you doing here," or words to this effect, and promptly got on the phone with his counterpart at Deal Junior High School, one of the

36 See Frank T. Read \& Luch S. McGough, Let Them Be Judged: The Judicial InTEgration If the Deep South 159-61 (1978).

37 See "In New Orleans, Major School District Closes Traditional Public Schools for Good," May 28, 2014, available at http://www.washingtonpost.com/local/education/in-new-orleans-traditional-public-schools-close-for$\mathrm{good} / 2014 / 05 / 28 / a e 4 f 5724-e 5 d e-11 e 3-8 f 90-73 e 071 f 3 d 637$ story.html (visited 10/29/14). 
very few D.C. junior high schools with more than a token number of white students. Within hours, the student had successfully transferred to Deal.

The failure of integration - in Washington, D.C., New Orleans, and throughout the country - is largely the product of individual choice by white families who fled integrated schools to the suburbs or to private education. A hypothetical judge who completely rejected legal liberalism's limits might have done something about this problem. One could imagine a society where parents were required to send their children to public school or where, at a minimum, city and suburban school districts were consolidated.

But even Judge Wright was unprepared to go this far. In Hobson itself, he ruefully acknowledged that he had no power to stop white flight, and although he urged the District's Board of Education to explore the possibility of coordination with suburban school districts, he admitted that he lacked authority to order inter-district desegregation.

Even so, Wright did not completely give up. In the immediate wake of Hobson, he immersed himself in the minute details of school boundary disputes, once again pressing against conventional notions about legal limits on judicial power. And when even his extraordinary efforts failed to produce integration, he dramatically embraced the old "separate but equal" requirement and ordered equalization of teacher expenditures in black and white schools. ${ }^{38}$

Wright's many critics claim that these efforts destroyed the District's system of public education. That claim is surely hyperbolic if not completely false, but no objective person can claim that his intervention achieved the goals he set for himself. It became increasingly clear that no tinkering with school boundaries could stem the massive outflow of white students from the system. Wright was helpless when the City implemented his equal expenditure order in the most cynical possible fashion,

38 See Hobson v. Hansen, 327 F. Supp. 844 (D.DC 1971). 
transferring highly paid but ineffective senior teachers to black schools while concentrating highly motivated, but underpaid junior teachers to the white schools. Ultimately, Wright had no choice but to relinquish jurisdiction over the case and watch from the sidelines as the school system degenerated into ever worse racial isolation and educational failure.

Although less dramatic, the story of Wright's engagement with tenant and consumer rights has a similar denouement. On conventional, neo-classical economic premises, Wright's regulatory interventions in these markets was bound to backfire. Because he could not and did not completely control private markets, ordinary market transactions would undo the effect of the regulation. Thus, raising landlords' costs produces less investment in low income housing, and constraining "predatory" credit terms reduces the availability of credit.

The economics behind these assertions is contested and complicated and I make no claim to the expertise necessary to adjudicate the dispute. One thing is certain, though. Nothing Wright did or had the power to do could increase the supply of credit and housing for poor people. Not that he didn't try. In one remarkable decision, for example, he came close to holding that a landlord was legally required to bring an apartment building up to code before he took it off the market. ${ }^{39}$ But even Wright had to acknowledge that quixotic measures like this would not remedy the systemic problems of the poor. As he conceded, decisions in individual cases would not "solve the housing crisis in the District of Columbia. That crisis is the product of a constellation of social and economic forces over which no court - and indeed perhaps no legislature - can exercise full control. ... [T] he judicial process is not a deus ex machina which can magically solve problems where the legislature and the executive have failed." 40

The prevalence of homeless people and of same-day-lending establishments on the streets of the District of Columbia today vouches for the truth of this statement. There is no proof that Wright's

39 See Robinson v. Diamond Housing Corp.,463 F. 2d 853 (1972).

$40 \quad$ Id., at 871. 
jurisprudence made these problems worse, but neither is there much reason to think that his decisions made them better.

On a broader scale, though, the failure of Wright's brand of legal liberalism was caused by more than economics. The failure was ultimately cultural and political. Writing at the height of Wright's influence, Yale Professor Alexander Bickel, perhaps his most worthy intellectual adversary, predicted the failure of the legal liberal project. Suppose we concede arguendo that legality and neutrality are not the proper criteria for good law. Activist liberal judges, Bickel wrote, should then be held to a standard based on whether they accurately predicted the future. But, as Bickel himself predicted, the future was moving away from Warren Court idealism. ${ }^{41}$

Judge Wright saw a very different future. In a direct challenge to Bickel, he argued that the Warren Court experience had permanently changed the legal landscape. "No amount of experience will substantially dull the inspiration of the 1960's. ... The students of this decade ... have seen that affairs can be ordered in conformance to constitutional ideals and that injustice--to which they are prepared to give powerful meaning--can be routed." 42

Two generations later, it seems pretty clear that Bickel made the better prediction. I do not mean to say that the Warren Court produced nothing of lasting value. Some of its reforms were important, and some of them stuck. Still, even the Warren Court's most fervent supporters would have to concede that political support for deep social reform through the mechanism of judicial review has not stuck. At the very moment when Wright and Bickel were engaged in this debate, American political culture had already begun to move decisively to the right in ways that have transformed the law. Today, the most salient constitutional issues of the 1960's - desegregated schools, meaningful protection of

41 See AleXAnder Bickel, The Supreme Court And the IdeA of Progress (1978).

42 J. Skelly Wright, Professor Bickel, the Scholarly Tradition, and the Supreme Court, 84 HARV. L. REV. 769,804 (1971) 
voting rights, constitutional protection for the poor, affirmative constitutional obligations to remedy injustice - are off the table. A reader of today's law review articles and judicial opinions will find that virtually all of the social ambition at the heart of Judge Wright's vision has been stripped out of constitutional law. Whereas liberalism and legality were once merely side constraints, they are now the point of the enterprise. What is left of progressive constitutionalism revolves around liberal privacy and individualism as embodied by abortion rights and the right to same-sex marriage. Moreover, debate about these and other constitutional issues is dominated by concern for original meaning and the rule of law.

\section{V.}

So what are we to make of this man and of his work? There are two versions of the story. I am not a legal liberal, so the tragic version comes easily to me. On this view, Skelly Wright was a good and decent man who was, nonetheless, misguided. Like all of us, he could not perfectly foresee the future. In the intoxicating environment of the 1960s, it was easy to think that the transformation he imagined was possible. No one should blame him for failing to anticipate the dramatic changes in our politics and culture that occurred. Nonetheless, with the benefit of hindsight, we can see that although Wright's courage and devotion to social justice were commendable, the notion that his ends could be achieved through the mechanism of judicial intervention was quixotic. Legal rhetoric alone cannot dislodge powerful and deeply entrenched interests. Law is not the source of social power, but its manifestation. The effort to use legal obligation as an engine for social change was therefore bound to fail.

More damning still, perhaps that effort should fail, at least to the extent that it is premised on constitutional interpretation. Why, after all, should people be forced to accept a contestable version of justice that do not otherwise appeal to them just because of a controversial claim that an ancient and ambiguous constitutional text requires them to do so? For its critics, legal liberalism in its constitutional 
form - even when it is open hearted, tolerant and pushed to its limits- is unacceptably authoritarian. It commands when it should persuade, obfuscates when it should clarify.

This version of the story is, by now, depressingly familiar. It is the version told by people like me -- disillusioned survivors of the 1960's who think of themselves as older and wiser. But this is not the story that Skelly Wright would tell about himself, and the least we can do for the memory of this wonderful human being who can no longer speak for himself is to try to give voice to his version.

Ironically, given the indisputable fact that Judge Wright was an activist, his version begins with a realistic assessment of the limits of judicial power. Skelly Wright did not create and was not responsible for the political and ideological constraints that bounded his effectiveness. Through an accident of history, he found himself a judge in mid-twentieth century America. He had no choice but to use the limited tools available at that time and in that place. As it happens, the main tool he had was legal rhetoric, and he used the tool with considerable skill and endless determination to advance the cause of justice.

Wright was a practical reformer. He was deeply idealistic, but one of his great strengths was his ability to temper his idealism with a sense of what could be accomplished in the real world. He had no patience for those who awaited a revolution that would never come or insisted on martyrdom that accomplished nothing. When there are real people who are suffering and need help, he believed that radical posturing was morally irresponsible.

When doing big things was impossible, Wright cheerfully satisfied himself with doing smaller things. And when one thing didn't work, he tried another. His career was marked by doggedness, resourcefulness, and optimism - not the stuff of tragedy. His life-long effort to hang onto both the decent and the practical in a deeply imperfect world provides an argument for persistence rather than surrender. 
Moreover, even if Wright's decisions did nothing else, they empowered people who were not accustomed to exercising power. African Americans in Jim Crow Louisiana and poor people fleeced by merchants and evicted from their homes in inner city Washington spent their lives on the receiving end of power. It must have been an exhilarating experience to find a judge willing to discipline the smug and arrogant people who regularly disciplined them. Perhaps the students growing up in the 1960's were not permanently transformed by the Warren era as Wright hoped, but who can say what effect he had on the dispossessed who found their way into his courtroom?

Finally, and most significantly, it is a vast oversimplification to suppose that Wright's vision has been discredited. On the contrary, his example presaged the frustrating, compromised, unsatisfying, maddening, and yet occasionally triumphant and heroic struggle of another great liberal reformer Barack Obama.

Of course, there are important differences between Wright and Obama. Wright was a judge, not an elected politician. He was somewhat more constrained by existing rules and precedent, but less constrained by overtly partisan politics than Obama. Perhaps in part because of this difference, perhaps because of temperamental differences, Obama is far more cautious than Wright was. Still, had he lived, there can be no doubt that Wright would have deeply identified with Obama.

Like Wright, Obama operates within the bounds set by legalism and liberalism. For example, the Affordable Care Act, like many of Wright's reforms, is flawed, perhaps fatally, because it operates within a framework of private markets and individual choice. Obama's ineffectual response to the threatened government default, like Wright's response to persistent racial segregation, was limited by respect for the rule of law.

Yet like Wright, Obama has managed to produce occasional triumphs over great odds. It is simply a fact that gay men and lesbians now serve openly in the armed forces, that millions of 
Americans who were one sickness away from disaster now have health insurance, that banks and financial institutions are better regulated, and that a beginning has been made toward the mitigation of the climate change that threatens our planet.

Perhaps all this, too, will be for naught. It is entirely possible that historians will view Obama's presidency as also ending in failure and tragedy. There can be no doubt that his reputation has been tarnished by compromise and half-measures. Yet the same haunting question that one asks about Wright must also be asked about Obama: Given the political and cultural constraints under which he operates what else would one have him do?

Like Obama, Skelly Wright was too clear eyed and practical to spend much time worrying about what could have been accomplished if the world were different. He confronted the world that existed, and he tried his best with the means available to him to make it better. He did so with verve, compassion, cheerfulness, and determination.

What more could one expect? 